\title{
Tax Allowance Policy to Increase Investment Climate in Fishery Sector
}

\author{
Wiji Mutia Hardianti ${ }^{1}$, Milla Sepliana Setyowati ${ }^{2}$ \\ \{wiwimutiah@kkp.go.id'1 , milla.s.setyowati@gmail.com ${ }^{2}$ \} \\ University of Indonesia, Indonesia ${ }^{1,2}$
}

\begin{abstract}
As one of the largest fish producers in the world, Indonesia's total production of fisheries sector reach 25 million tons per years and its export volumes has increased up to $12.82 \%$ growth. Fisheries production has also contributed to Gross Domestic Product (GDP) with $6.79 \%$ in Q3 2017, higher than National GDP with 5.03\%. The President of Indonesia established a new vision to strengthen Indonesia position as a maritime country. It is to make Indonesian sea as the future of the Nation. In order to boost fishery sector development, the government has launched a Tax Allowance Policy which is targeting domestic and foreign investment. This study aims to analyze the implementation of tax-allowance policy in order to attract investors in the certain business fields and certain areas of fishery sectors. This facility is not well-utilized by the investors in fishery sectors compared to other sectors. It's only one company that have been approved to get the facility until 2019. This study uses a qualitative approach with data collection methods in the form of in-depth interview and secondary data. The results of this study show that policy contents and some rules affect the policy implementation. The Ministry of Marine Affairs and Fisheries must review the appropriate business fields to be given the tax allowance facility and conduct the socialization intensively.
\end{abstract}

Keywords: Policy Implementation, Tax Facility, Fishery Sector.

\section{Introduction}

As an archipelagic country with an area of 5.8 million $\mathrm{km}^{2}$ of water and the longest coastline among other island countries, which is $95,181 \mathrm{~km}$, Indonesia's marine and fisheries sector holds enormous potential. In the context of global trade, Indonesia is currently strengthening its position as the world's maritime axis. This is reinforced by Indonesia's new maritime vision contained in one of the points of Nawa Cita, namely strengthening the identity of the Maritime State.

Indonesia's fisheries sector is getting special attention because it is very prospective for the economy. According to the Ministry of Marine Affairs and Fisheris (MMAF) [1] Performance Report in 2018, the production of Indonesian marine fisheries reached 24.29 million tons. This number rose $1.41 \%$ from the previous year at 24.15 million tons. The value of Indonesian fishery exports increased by $7.52 \%$, which was 4.52 billion in 2017 to 4.86 billion USD in 2018. The fisheries sector has also provided tangible evidence with Fisheries Production Results that contributed greatly to Gross Domestic Product (GDP) as can be seen in Figure 1. GDP growth of fisheries up to Quarter III of 2017 reached 6.79\% while National GDP growth was still at $5.03 \%$. 
The GDP target for fisheries in 2019 is recorded in the 2015-2019 KKP Renstra, which is $11 \%$. The action plan to be taken in an effort to increase the GDP of fisheries in the future is through increasing fisheries production, improving the investment climate, and improving supply chain from upstream to downstream.

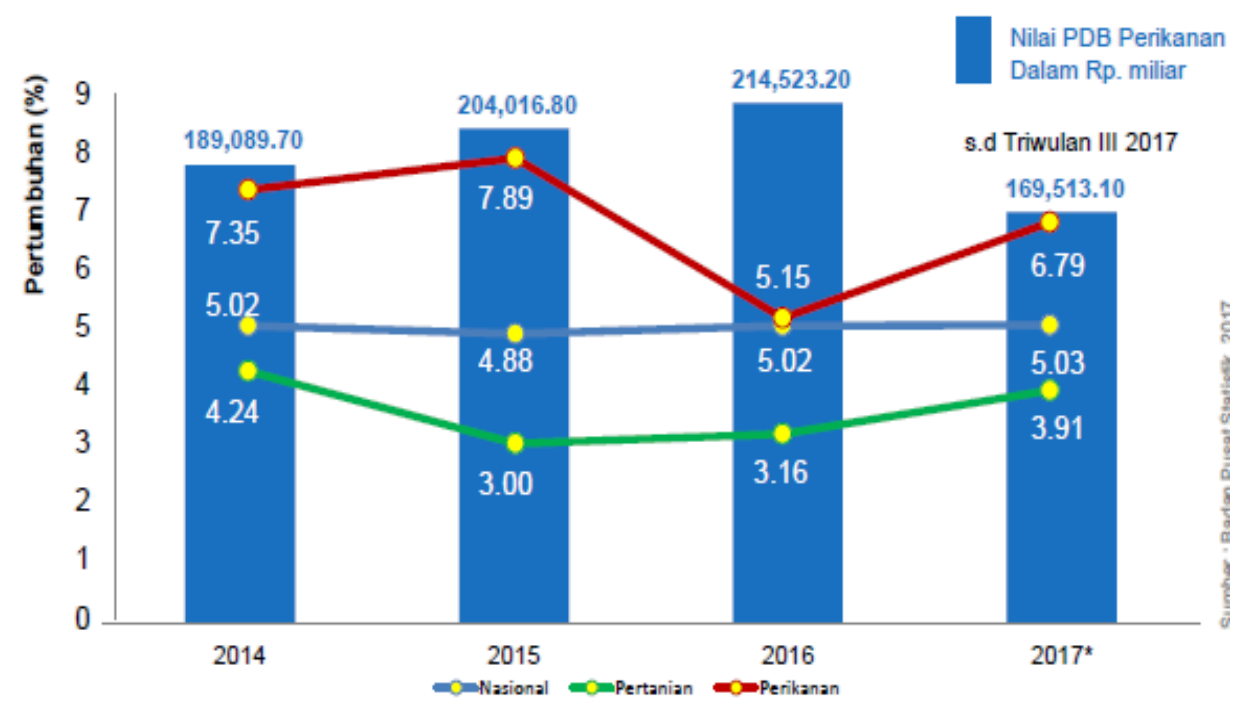

Figure 1. Fish Production Contribution to GDP

Source: The 2017 Central Bureau of Statistics which has been processed by the MMAF.

Behind the great economic potential, there are several issues in the management of marine fisheries in Indonesia that also have the potential to threaten economic growth, especially those sourced from the use of marine and fisheries resources such as; a decrease in the number of fisheries households, limited infrastructure in aquaculture and fisheries development, low productivity and competitiveness of marine and fisheries businesses due to the lack of optimal integration of production systems in upstream and downstream areas, weak competitiveness and productivity due to quality, limited business capital support from banks and other financial institutions to fishermen/farmers.

In order to optimize the utilization of the potential of the sea for the welfare of the Indonesian people, the government is currently aggressively combating Illegal, Unregulated, Unreported (IUU) Fishing by stipulating Presidential Regulation Number 44 of 2016 concerning List of Closed Business Fields and Open Business Fields with Field Requirements Capital investment. With this rule, the capture fisheries sector must come entirely from within the country. As for foreign investors, Indonesia still provides a 100 percent opportunity to invest in downstream fisheries activities, namely fish processing business.

The Ministry of Maritime Affairs and Fisheries [2] has also begun to implement a Fisheries Industry Acceleration Program as a follow-up effort from the issuance of Presidential Instruction Number 7 of 2016 concerning the Acceleration of the Development of the National Fisheries Industry. KKP began to build Integrated Marine and Fisheries Centers (SKPT) as new industries in the outer islands that are close to export gate away. KKP Director General of Marine Space Management, Brahmantya Satyamurti Poerwadi, in the book "Our 
Sea is the Future of the Nation" (2018), said that in the construction of the SKPT Indonesia needed investment in cold storage facilities, processing industries, port construction, ship building, coaching, and so on. With the revitalization through this investment, it is expected that the fishing industry can move forward and exports can continue to grow.

Based on the KKP Performance Report 2017, investments in Marine and Fisheries Products consist of Foreign Investment (PMA), Domestic Investment (PMDN), and investment credit (Table 1). The investment value of marine and fishery products is targeted at 5.94 trillion in 2017. Until December 2017, the realization of investment value reached 4.83 trillion or $81.32 \%$ of the 2017 target. The investment value achievement was dominated by investment credit compared to PMA and PMDN, which amounted to $57.97 \%$ in 2017. Furthermore, based on data from the Indonesian Investment Coordinating Board (BKPM), the realization of Domestic Direct Investment (DDI) and Foreign Direct Investment (FDI) according to sectors in Indonesia showed a lagging result compared to other sectors. The percentage contribution of the realization of the investment in the fisheries sector to the realization of national investment does not move up from the figure of $0.1 \%$ per year, with the largest investment value in 2015 which is IDR 0.7 Trillion. With the condition of the maritime and fisheries sector that is far better than in previous years, investment should continue to be encouraged to strengthen the national fishing industry.

Investment is expected to generate multiplayer effects on national economic development, because investment activities not only transfer goods and capital, but also transfer knowledge [3]. To attract investors to invest in this fishing industry, Indonesia has offered several conveniences. One of them is an income tax relief facility for foreign and domestic investors who are interested in investing. According to Irianto and Rosdiana [4], that the policy of reducing the tax burden will not reduce aggregate revenues, on the contrary it increases state revenues from other types of taxes.

The Income Tax Incentive for investment is based on Article 31A of Law Number 36 of 2008 concerning Income Tax. The Government has issued Government Regulation No. 18 of 2015 [5] as amended into Government Regulation Number 9 of 2016 concerning the provision of facilities for tax allowances (reduction of income tax) for investment in certain business fields and / or in certain areas in order to boost economic growth. This facility is intended for domestic taxpayers who make new investments or expand existing businesses, as long as they meet the criteria of having a high investment value or for export, have a large employment, and have a high local content.

As a derivative rule, the Ministry of Maritime Affairs and Fisheries (KKP) [6] issued an implementing regulation from the Government Regulation namely Minister of Marine and Fisheries Regulation Number 17 of 2015 concerning Criteria and / or Requirements for Giving Income Tax Facilities for Investment in Certain Business Fields and / or In Certain Areas in the Marine and Fisheries Sector. In this rule it is explained that the provision of income tax facilities is by criteria; have a high investment value (at least 10-50 billion) or for exports (at least $30 \%-80 \%$ of the products are exported) or have a large employment (at least $90 \%$ of Indonesian labor). Eleven business sectors in the marine and fisheries sector will be given fiscal incentives in the form of tax-allowance facilities.

The government has made changes to the Government Regulations that regulate the provision of tax allowances from year to year by adding the number of Indonesian Standard Business Classifications (KBLI) that these facilities can provide. However, the utilization of tax allowance facilities in the marine and fisheries sector businesses themselves is still not optimal. Data from the CTF's Directorate of Business and Investment shows that the realization of companies that register for tax allowance facilities in the fisheries sector is nil in 
2016, whereas in 2017 only 1 company registered to be given a tax allowance under the name of the company "Indomina Langgeng Abadi "From Lampung. The company has business activities in the field of shrimp cultivation and processing, with an investment value of 200 billion.

\section{Theoretical Review}

\subsection{Tax as a National Development Instrument}

Every country has a national development program as an effort to realize the goals and ideals of the nation and state. To realize these programs, the government needs sufficient funding sources to achieve the targets set. Tax is expected to be a driving force for the national development programs [4]. Furthermore Alink and Kommer [7] also state that taxes are the main source of income and a tool to regulate the market in order to finance 4 main areas in service to the public by governments such as; (1) to protect (protection from natural disasters); (2) to insurance (national health, unemployment, poverty); (3) to care (for the elderly, children and minorities); and (4) to educate (from elementary school to access to colleges, libraries, and free information media).

\subsection{Tax Policy}

According to Mansury in Rosdiana [4] , Tax Policy is a fiscal policy in a narrow sense. Fiscal policy in the broadest sense is a policy to influence public production, employment opportunities, and inflation, using instruments to collect taxes and expenditure on the State. Whereas in the narrow sense, the fiscal policy is related to the determination of tax-base, who is taxed and excluded, what is the object of tax and excluded, how to determine the amount of tax payable and the procedure for implementing the tax liability.

\subsection{Policy Implementation}

Grindle [8] argues that there are two variables that influence the success of a policy implementation, namely Content of Policy and Context of Implementation. The explanation of the Grindle policy implementation model is as follows:

1. Content of Policy (Fill in the Policy)

Some indicators of variables that influence policy are:

a. Interest Affected (interest of the target group)

b. Type of Benefit

c. Extent of Exchange Envinsion (degree of change to be achieved)

d. Site of Decision Making (where decision is made)

e. Program Implementer (program implementer)

f. Committed resources (availability of resources)

2. Context of Implementation (Implementation environment variable)

a. Power, interests and strategies of the actors involved;

b. Characteristics of the institutions and regimes in power;

c. Compliance and responsiveness (response from implementing policies). 


\subsection{Investment}

Gunadi in Rahayu and Santoso [9] mentioned several types / forms of investment, including:

1. Real Investment vs Financial Investment

One example of the form of real investment is the construction of a factory, because it involves tangible assets. While investment in the form of stocks and other securities is referred to as financial investment

2. Equity vs. Loan Investment

Equity Investment means participation in corporate capital through share ownership. While debt (loan0 investment is an investment in the form of lending / debt.

3. Direct vs. Investment Portfolio

Direct investment is an investment with the aim of establishing a long economic relationship with the company (Investee Company) and having an effective influence in the management of the company. Investors will participate or oversee the process of earning income. While portfolio investment is an investment in the form of equity participation in a small portion $(10 \% /<25 \%)$. Also referred to as non-entrepreneurial investment of capital. In this type of relationship between investors and companies is better than direct investment.

\subsection{Income Tax Incentive Policy}

Many developing countries offer income tax incentives to encourage investment. Most often incentives are given to direct investors rather than portfolio investors, which are related to real investments in productive activities rather than investments in financial assets. Incentives are often aimed at foreign investors on the grounds that domestic capital is inadequate, and the development of international investment brings with it modern technology and management techniques. Incentives are also intended to offset other losses that investors may face, such as lack of infrastructure, complicated and old-fashioned laws, the complexity of bureaucracy and weak administration, both in the tax area or other sectors [10].

\section{Methods}

This study uses a qualitative descriptive approach. The data has been collected through literature study and field study which are done through in dept interview with the policy makers and the policy implementers. The technique for determining the informant is the method of key person and snowball. The interviewees in this study came from the Ministry of Maritime Affairs and Fisheries, the Investment Coordinating Board, the Fiscal Policy Agency, the Coordinating Ministry for Economic Affairs, and the Directorate General of Taxes. The data will be analyzed with Policy Implementation Model by Grindle with 2 variables; Content of Policy and Context of Implementation. 


\section{Discussion}

\subsection{Content of Policy}

The indicators for variables that influence policy are:

a. Interest Affected (interest of the target group)

One of the criteria in Annex II of Minister of Marine Affairs and Fisheries Regulation Number 17 Year 2015 states that integrated capture fisheries are capture fisheries with investment facilities integrated with fish processing through development, having a Fish Processing Unit, or partnering with a Fish Processing Unit. This criterion can be an obstacle in implementation because many fishing entrepreneurs whose tangible assets to do business are in the form of vessels and fishing equipment, without being integrated with fish processing or in port areas that do not yet have facilities for fish storage and processing.

b. Type of Benefit

Indicators that indicate that the policies made can show or explain some of the benefits that have a positive impact that can be generated from the policy. Of course, with this policy, it indicates if there is a significant amount of tax expenditure that is a burden on the government. But the expected long-term impact is the creation of a multiflyer effect that will increase the tax revenue itself. This is as stated by the Head of the Agency for Corporate Income Tax, DGT as follows: One of the criteria for obtaining a tax allowance is a large absorption of energy. If a new business already exists and produces, then he will grow the economy around him. Taxes will be reduced by a few percent for the first 6 years, then once more workers and production increases, it is a new tax object. There will be more people who will pay taxes later.

c. Extent of Exchange Envision

An indicator that shows the degree of change you want to achieve. The contents of the policy will affect what is produced. Changes that are to be achieved can be in the form of long-term programs that require changes in people's behavior.

This is in line with the opinion of the Head of the MMAF Facility Services Section which states that sometimes entrepreneurs do not want to show the actual investment, because they do not want to deal with taxes. Indeed, later they will not get tax benefits, but eventually he will report the actual tax. Tax Issues in Indonesia, only $30 \%$ of people report actual results. Providing this facility actually also unmasks the company's financial statements.

In principle, without any facilities, DGT has the authority to test the financial statements of a company. In Article 12 KUP, the Tax Return (SPT) is correct unless the DGT has proof that the SPT is wrong. If taxpayers feel the report is correct, there is nothing to worry about. For 6 years before the stipulation period expires, the DGT can check at any time. Both people who get facilities and those who do not (Head of Corporate Income Tax Section, Directorate General of Taxes)

d. Site of Decision Making

This indicator shows that decision making from a policy is an important matter. One of the mandates of Government Regulation No. 18 of 2016 is that each sector regulates its own sector. In the fisheries sector itself, the Minister of Maritime Affairs and Fisheries Regulation Number 17 of 2015 [11] has been issued as a derivative regulation. Determination of the feasibility of the business field that submits the application is at the Ministry of Trustees of the 
sector. Because it is the sector ministries that are most aware of their respective fields. What is the value of the company's investment, is the source of the raw material legal, and so on. That recommendation will later become a reference for Investment Coordinating Board and DGT to make a decision whether or not to accept the request (Head of Business Services Section, MMAF).

The data shows that for the fisheries sector itself since 2017 there have been 4 proposals that can be seen in Table 1. But those who get new facilities are 1 company. Three other companies were rejected with some notes such as; has been producing commercially when submitting, unable to separate business expansion assets, and principle permits issued before the issuance of Government Regulation Number 18 of 2016.

Tabel 1. Businesses in the Marine and Fisheries Sector Who Apply for Tax Allowance

\begin{tabular}{|c|l|l|l|l|}
\hline No. & $\begin{array}{c}\text { Companies } \\
\text { Name }\end{array}$ & \multicolumn{1}{|c|}{$\begin{array}{c}\text { Business } \\
\text { Fields }\end{array}$} & \multicolumn{1}{|c|}{ Investment Plan } & \multicolumn{1}{|c|}{ Explanation } \\
\hline 1 & $\begin{array}{l}\text { PT. Bumi } \\
\text { Pangan } \\
\text { Utama }\end{array}$ & $\begin{array}{l}\text { Other Biota } \\
\text { Air freezing } \\
\text { industries }\end{array}$ & $\begin{array}{l}\text { Rp. 300 Billion, } \\
\text { Domestic Direct } \\
\text { Investment in Banten }\end{array}$ & $\begin{array}{l}\text { Not received the tax } \\
\text { allowance facility due to } \\
\text { submission after the } \\
\text { company operates } \\
\text { commercially }\end{array}$ \\
\hline 2 & PT. Perinus & $\begin{array}{l}\text { Fish Freezing } \\
\text { Industry }\end{array}$ & $\begin{array}{l}\text { Rp. 1.34 Billion, } \\
\text { Domestic Direct } \\
\text { Investment in } \\
\text { Maluku, Malut, } \\
\text { Papua Barat }\end{array}$ & $\begin{array}{l}\text { Can not separate business } \\
\text { expansion assets }\end{array}$ \\
\hline 3 & $\begin{array}{l}\text { PT. Wahan } \\
\text { Lestari } \\
\text { Investama }\end{array}$ & $\begin{array}{l}\text { Integrated } \\
\text { Shrimp } \\
\text { Cultivation }\end{array}$ & $\begin{array}{l}\text { Rp. 786 Billion, } \\
\text { Foreign Direct } \\
\text { Investment (Korea) }\end{array}$ & $\begin{array}{l}\text { Principle permits issued } \\
\text { before the issuance of } \\
\text { Government Regulation } \\
\text { Number 18 of 2016. }\end{array}$ \\
\hline 4 & $\begin{array}{l}\text { PT. Indomina } \\
\text { Langgeng } \\
\text { Sejahtera }\end{array}$ & $\begin{array}{l}\text { Freezing of } \\
\text { Another Biota } \\
\text { Water }\end{array}$ & $\begin{array}{l}\text { Rp. 222 Billion, } \\
\text { Domestic Direct } \\
\text { Investment in } \\
\text { Lampung }\end{array}$ & $\begin{array}{l}\text { Minister of Finance } \\
\text { Decree No. 97 / K.3 / } \\
\text { 2017 concerning } \\
\text { Approval for Granting } \\
\text { Income Tax Facility (Tax } \\
\text { Allowance) }\end{array}$ \\
\hline
\end{tabular}

Source: Directorate of Business and Investment, MMAF.

Further, the position of the Directorate General of Tax itself is in the post audit. Those who get the facility will certainly be the object to be monitored because there are some restrictions that they should not do, as long as the company uses its facilities (5\% for 6 years). The steps, on the internal side, are to conduct a gathering to discuss whether there is an incongruity or there are reports that are problematic. The routine that becomes the DGT's job desk is supervision of reporting (Head of Corporate Income Tax Section, DGT).

\section{e. Program Implementer}

It is an indicator that shows that implementing a policy needs to be supported by the availability of competent implementers to realize the success of a policy. Related to the implementation of the policy, this tax allowance consists of 2 parts. The first is related to regulations, namely the torso, and the second is related to various sectors. Regarding 
regulation, the Fiscal Policy Agency plays a role in determining Subjects, Objects, and Tariffs (SOT), the Directorate General of Taxes plays a role in administrative regulations, and the Investment Coordinating Board deals with all matters relating to investment. Then those related to the Ministry of Trustees of the sector, will be coordinated by the Coordinating Ministry for Economic Affairs. There are several sectors contained in Attachments I and II of Government Regulation No. 18 of 2016 and Coordinating Ministry for Economic Affairs which is deemed appropriate to coordinate various Ministries / Agencies related to the implementation of this tax allowance policy.

\section{f. Committed resources}

It is an indicator that shows the importance of the availability of resources that support the implementation of policies that have been made. The implementers are committed to continuing to maximize the implementation of this policy. This can be seen from the evaluation process which was carried out to revise business fields that could be added or even abolished. This is based on the results of an interview with the Deregulation Directorate of the Investment Coordinating Board which states that the evaluation is conducted at least every 2 years. If there is a business that already exists from previous regulations but is not utilized, it is possible to close. However, if there is a proposal to maintain the existing business sector or add a new business field, it will also be considered to encourage the sector.

Currently revisions to Government Regulation Number 18/2015 [5] are being carried out in the framework of simplifying procedures and accelerating efforts in accordance with Presidential Regulation 91/2017. The process of submitting a request for a tax allowance facility will later use Online Single Submission (OSS) where the process of issuing a decree which was originally 25 days will be reduced to 3 working days. The OSS implementation will also facilitate new investors and those who will expand their business to obtain information about this tax allowance facility (Interview with Head of Facility Section, Fiscal Policy Agency).

\subsection{Context of Implementation}

a. The power, interests and strategies of the actors involved

One of the criteria for obtaining this tax allowance is a business actor that has not produced commercially. In the fisheries sector itself, this criterion is also an obstacle factor in implementing the policy because most companies have already produced commercially. In addition, business actors in the capture fisheries sector are dominated by small fishermen in the Middle-Small Market Economy category, so it is more appropriate to be given $0.5 \%$ MSME tax facilities.

Business actors who have made sales, usually have formed a name for the tax base. The extreme is when PT XYZ has the same product as a new company, but it has been established from 1945, has routinely paid taxes, has made sales up to now and has formed a tax base. If it is not restricted provided that it has not produced commercially, the PT XYZ company can also obtain this facility. Therefore, this facility is ideally for attracting new investors, not providing facilities for existing investors, who already exist and have already paid taxes. If all existing companies are given facilities, then theres no tax revenue and the burden of government tax expenditures are increasing (Head of Section of Corporate Income Tax, Directorate General of Taxes).

b. Characteristics of the institutions and regimes in power 
Under the leadership of Minister Susi Pudjiastuti, many strategic policies have been issued with the intention of maintaining the sovereignty of Indonesian maritime affairs and fisheries. One of them is the moratorium on foreign vessels as mandated by the Presidential Regulation Number 44/2016. The negative list of foreign investments makes capture fisheries only manageable by domestic investors.

In implementing this tax allowance policy, it certainly must be in line with the regulations above. Government Regulation Number 18/2015 cannot be separated from Presidential Regulation Number 44/2016, so that it can be one of the factors of the small realization in tax allowance receiver. Investment in capture fisheries is a large investment, facilities and infrastructure such as ships and fishing equipment. As well as storage facilities at the port. Not many domestic investors in the country are capable of this sector, there will be no automatic proposing in this sector (Directorate of Business and Investment, MMAF).

In implementing the tax allowance policy, itself there is no political issues that are being the obstacles. However, in an effort to attract investment, the tax facility itself can only be said as a "sweetener" where many non-tax factors that affect interest in investments such as political stability, economic stability, security and availability of infrastructures. If investors feel that all these basic factors have been fulfilled, then they will invest. Indonesia itself, including the country with good political and economic stability, is also an extraordinary market. If business-people know that there are such tax facilities, it is very unlikely that they are not interested. Because with the tax allowance, business people will get a great amount of tax savings.

c. Compliance and responsiveness (response from implementing policies)

The number of Standard Classification of Business Fields in the Attachment of Tax Policy Regulation tends to increase since Government Regulation Number 52/2011 as shown in Fig.2. However, utilization in the fisheries sector has not been maximized. The derivative rules in the fisheries sector itself were only issued after the Government Regulation Number $1 / 2015$.

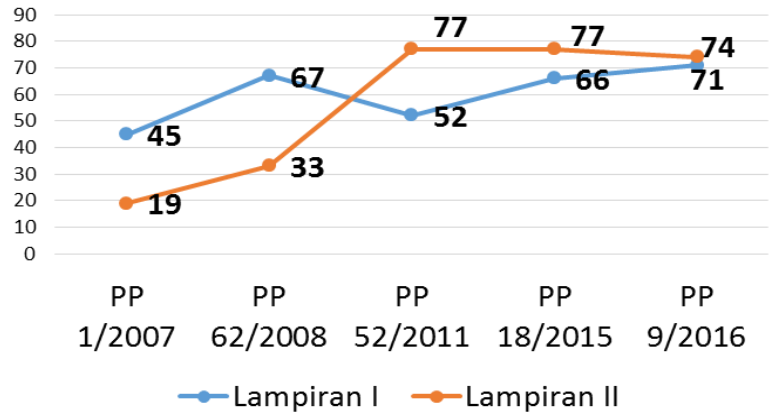

Figure 2. Amount of KBLI in the Appendix of Government Regulations concerning Tax Allowance

Source: Indonesia Investment Coordinating Board

From the interviews with Investment Coordinating Board, DGT, and Fiscal Policy Agency, results were obtained that the MMAF as the lead of the fisheries sector was deemed less active in coordinating with other ministries / institutions involved. Compared to the ministries of 
industry and Ministry of Energy and Mineral Resources, MMAF is rarely come when invited to a coordination meeting regarding the implementation of a tax allowance. The Head of Facilities Section of the Fiscal Policy Agency said that even if he came, it would never be the same person. So that the information obtained is not intact, because it requires qualified people to be able to implement this policy to the fullest. The lack of socialization by the MMAF is also one of the factors not maximizing implementation. So that there are still many business people who do not yet know that there is a tax allowance facility.

\section{Conclusion}

In order to maximize the utilization, MMAF should conduct a review of the list of business fields that facilities can provide. It is possible that the criteria in the derivative rules are not in accordance with the reality in the field, both to the minimum investment value, the source of raw materials and the availability of infrastructure, and business fields that need to be developed. Thus making Minister of Maritime Affairs and Fisheries Regulation Number 17 of 2015 [11] less applicable because business people feel the criteria are too difficult.

\section{References}

[1] M. of M. A. and Fisheries, "Kementerian Kelautan dan Perikanan Dalam Angka Tahun 2015." [Online]. Available: http://kkp.go.id.

[2] M. of M. A. and Fisheries, "Laut Kita Masa Depan Bangsa: Akses Modal Mendorong Kesejahteraan (2018).”.

[3] D. A. Ridgway and M. A. Talib, "Globalization and Development-Free Trade, Foreign Aid, Investment and the Rule of Law," Cal. W. Int'l LJ, vol. 33, p. 325, 2002.

[4] R. Haula and E. S. Irianto, "Pengantar Ilmu Pajak, Kebijakan dan Implementasinya di Indonesia.” Jakarta: Rajawali Press, 2012.

[5] Government Regulation No. 18/2015 on Income Tax Incentives for Investment in Certain Business Fields and/or in Certain Areas.

[6] M. of M. A. and Fisheries, "Laut Kita Masa Depan Bangsa: Upaya tingkatkan produksi dan ekspor produk perikanan Indonesia (2018).".

[7] M. Alink and V. Van Kommer, Handbook on tax administration. IBFD, 2011.

[8] M. S. Grindle, Politics and policy implementation in the Third World, vol. 4880. Princeton University Press, 1980.

[9] I. dan N. R. Santoso, "Corporate Tax Management: Mengulas Upaya Pengelolaan Pajak Perusahaan Secara Konseptual-Praktikal,” Obs. Res. Tax. (ortax), Jakarta, 2013.

[10] V. Thuronyi, Tax law design and drafting, vol. 2. International Monetary Fund, 1998.

[11] Ministerial Regulation No. 17/PERMEN-KP/2015 on the Criteria and/or Requirements for Provision of Income Tax Facilities for Investment in Certain Business Fields and/or in Certain Areas in the Marine and Fisheries Sector. 